\title{
OESTRADIOL CONCENTRATION IN THE PERIPHERAL PLASMA OF THE DOMESTIC HEN FROM 7 WEEKS OF AGE UNTIL THE TIME OF SEXUAL MATURITY
}

\author{
B. E. SENIOR \\ National Institute for Research in Dairying, \\ Shinfield, Reading RG2 9AT
}

(Received 2nd January 1974)

\begin{abstract}
Summary. A specific radioimmunoassay technique was used to measure the concentration of oestradiol at weekly intervals in the blood plasma of seven pullets from 7 weeks of age until they were sexually mature. Large differences in oestradiol concentration were observed between birds. The mean concentration was $94 \mathrm{pg} / \mathrm{ml}$ plasma 7 weeks before the first egg was laid. The concentration then began to rise sharply 2 to 3 weeks later to reach a peak of mean value $355 \mathrm{pg} / \mathrm{ml}$ 2 to 3 weeks before laying began. The mean concentration when egglaying was established was $138 \mathrm{pg} / \mathrm{ml}$. The high oestradiol levels found before the onset of laying may be essential for the synthesis of yolk protein precursors and for the conservation of calcium as medullary bone in preparation for egg-shell formation. The peak may also be an important part of the changes which occur at puberty in the interrelationship between the hypothalamus, the pituitary gland and the ovary.
\end{abstract}

\section{INTRODUCTION}

Considerable changes in the blood composition of immature chickens or adult cockerels occur after oestrogen administration (Lorenz, 1954; Urist, 1959). The appearance in the plasma of the egg-yolk protein precursors, phosvitin and lipovitellin (Gruber, 1972), and the increase in the total calcium concentration are of the most direct relevance to reproduction. In the presence of androgens, oestrogens cause calcium to be deposited and stored as medullary bone (Benoit \& Clavert, 1945), a soft bone tissue which invades the marrow cavity of long bones (Kyes \& Potter, 1934) and which acts as a buffer against large fluctuations in calcium requirements (see Simkiss, 1967). All of these components as well as others under oestrogenic control, such as plasma proteins and lipids, increase in concentration as hens become sexually mature (Vanstone, Maw \& Common, 1955; McIndoe, 1959; Heald \& Badman, 1963; Redshaw \& Follett, 1972). The finding that oestrone reaches a peak level in urine a few days before egg-laying begins (Common, Ainsworth, Hertelendy \& Mathur, 1965; Mathur, Anastassiadis \& Common, 1966) is in agreement with 
the view that these changes occur under the influence of endogenous oestrogens.

The hormonal interrelationships between the ovary, the pituitary and the hypothalamus in the hen are still far from clear (Gilbert, 1971) and the changes in these interrelationships during sexual maturation are virtually unknown.

An examination of the blood oestradiol levels up to the time of sexual maturity was therefore undertaken to determine whether changes in oestradiol concentration accompany the metabolic changes which occur during maturation, and to provide some information on the hormonal regimen under which ovulation commences.

\section{MATERIALS AND METHODS}

Seven birds (Sussex White pullets $\times$ Rhode Island Red cockerels), hatched on 12th November 1971, were reared to sexual maturity. From 7 weeks of age, they were accommodated in three adjacent wire cages and were subjected to $14 \mathrm{hr}$ light/day throughout the entire rearing period. They were fed a chick mash up to 11 weeks of age, after which they received a standard grower's ration.

Samples of blood $(2 \mathrm{ml})$ were removed from each bird between 09.30 and 10.30 hours at 7 and 10 weeks of age and weekly samples were removed thereafter until $1 \frac{1}{2}$ to 2 weeks after the first egg was laid. The successive samples were removed from alternate brachial veins into a heparinized syringe. The blood was immediately cooled to $4^{\circ} \mathrm{C}$ and the plasma was separated and stored at $-20^{\circ} \mathrm{C}$ until it was assayed. All samples from a given bird were assayed at the same time to eliminate interassay variation.

Oestradiol was assayed by the radioimmunoassay procedure described previously (Senior, 1973,1974$)$. Plasma $(0.5$ to $1.0 \mathrm{ml}$ ), to which was added $16,000 \mathrm{~d} / \mathrm{min}(20 \mathrm{pg})$ of $\left[{ }^{3} \mathrm{H}\right]$ oestradiol-17 $\beta$, was extracted with three $5-\mathrm{ml}$ quantities of diethyl ether. The dried ether extract was chromatographed on a $15-\mathrm{cm}$ long column of Sephadex LH-20, using the solvent system $15 \%$ methanol and $85 \%$ toluene. The fraction of the eluate containing oestradiol was evaporated to dryness and incubated overnight at $4^{\circ} \mathrm{C}$ with a diluted antiserum preparation. An aliquot of the incubate was removed to estimate the total radioactivity in the assay tube and also to determine the loss of oestradiol throughout the procedure. Bound and free radioactivity were separated using dextran-coated charcoal. The values for the percentage of radioactivity bound to the antiserum were compared with those for standard quantities of oestradiol$17 \beta$. The assay was able to detect concentrations as low as 20 to $30 \mathrm{pg} / \mathrm{ml}$ plasma. In six of the birds, single estimates were made on $1 \mathrm{ml}$ plasma. Samples from Bird M5 were assayed twice, using $0.5 \mathrm{ml}$ plasma for each assay.

The antiserum was prepared in sheep by injecting oestradiol-17-succinyl bovine serum albumin. It was capable of binding oestrone, oestradiol-17 $\alpha$ and oestriol to an extent which was $80 \%, 20 \%$ and $10 \%$, respectively, of the binding of oestradiol-17 $\beta$. The binding of all other steroids tested was less than $0.01 \%$ of that of oestradiol- $17 \beta$. The Sephadex LH-20 column procedure separated oestrone and oestriol from oestradiol-17 $\beta$ and oestradiol-17 $\alpha$, but the latter two oestrogens were not separated from each other. The oestradiol results presented, therefore, may include a contribution by oestradiol-17 $\alpha$. 


\section{RESULTS}

The age at which each bird laid the first egg is shown in Table 1. The first egg was never laid in isolation. The birds immediately began laying clutches of two to six eggs separated by inter-clutch intervals of only 1 day. Birds M1 and M5 began laying at $17 \frac{1}{2}$ weeks of age whereas the other five birds laid their first egg between 20 and 22 weeks of age.

Table 1. Concentrations of oestradiol in the peripheral plasma of hens from 7 weeks of age until sexual maturity

\begin{tabular}{|c|c|c|c|c|c|c|c|}
\hline \multirow[b]{2}{*}{$\begin{array}{c}\text { Age } \\
\text { (weeks) }\end{array}$} & \multicolumn{7}{|c|}{ Bird } \\
\hline & $\begin{array}{c}M 1 \\
\text { (122 days })\end{array}$ & $\begin{array}{c}M 2 \\
(147 \text { days })\end{array}$ & $\begin{array}{c}M 3 \\
\text { (149 days) }\end{array}$ & $\begin{array}{c}M 4 \\
(141 \text { days })\end{array}$ & $\begin{array}{c}M 5 \\
\text { (122 days) }\end{array}$ & $\begin{array}{c}M 6 \\
\text { (142 days ) }\end{array}$ & $\begin{array}{c}M 7 \\
(149 \text { days })\end{array}$ \\
\hline $\begin{array}{l}7 \\
10 \\
11 \\
12 \\
13 \\
14 \\
15 \\
16 \\
17\end{array}$ & $\begin{array}{r}40 \\
52 \\
72 \\
66 \\
72 \\
78 \\
124 \\
318 \\
142\end{array}$ & $\begin{array}{r}48 \\
50 \\
54 \\
70 \\
54 \\
96 \\
62 \\
106 \\
140\end{array}$ & $\begin{array}{r}72 \\
91 \\
65 \\
77 \\
72 \\
121 \\
79 \\
95 \\
130\end{array}$ & $\begin{array}{r}66 \\
93 \\
66 \\
78 \\
88 \\
150 \\
118 \\
82 \\
136\end{array}$ & $\begin{array}{c}43,56 \\
-5,78 \\
104,94 \\
91,86 \\
217,90 \\
477,356 \\
671,571 \\
432,439 \\
304,324\end{array}$ & $\begin{array}{r}69 \\
91 \\
92 \\
86 \\
120 \\
99 \\
105 \\
147 \\
194\end{array}$ & $\begin{array}{r}70 \\
116 \\
91 \\
100 \\
110 \\
123 \\
128 \\
210 \\
525\end{array}$ \\
\hline $\begin{array}{l}18 \\
19 \\
20\end{array}$ & $\begin{array}{l}112 \\
138\end{array}$ & $\begin{array}{l}218 \\
152 \\
166\end{array}$ & $\begin{array}{l}185 \\
152 \\
210\end{array}$ & $\begin{array}{r}104 \\
160 \\
\rightarrow 128\end{array}$ & $\begin{array}{r}180,174 \\
162,145\end{array}$ & $\begin{array}{l}254 \\
387 \\
114\end{array}$ & $\begin{array}{l}620 \\
980 \\
706\end{array}$ \\
\hline 21 & & $\rightarrow 20$ & 96 & 160 & & $\overrightarrow{172}$ & 173 \\
\hline $\begin{array}{l}22 \\
23\end{array}$ & & 80 & $\begin{array}{l}153 \\
215\end{array}$ & $\begin{array}{l}86 \\
92\end{array}$ & & $\begin{array}{l}115 \\
114\end{array}$ & $\begin{array}{l}107 \\
228\end{array}$ \\
\hline
\end{tabular}

The oestradiol concentrations are expressed in terms of $\mathrm{pg} / \mathrm{ml}$. The age at which the first egg was laid is shown in parentheses after each bird number. The arrow represents the approximate occurrence of the onset of laying.

The peripheral plasma concentrations of oestradiol are shown in Table 1 . Text-figure 1 shows the combined results, taking the time at which the first egg was laid as the reference point. Oestradiol levels began to rise sharply 4 to 5 weeks before the first oviposition, reached a peak 2 to 3 weeks beforehand and fell rapidly in the 2 weeks before egg-laying began. The peak was clearly shown in all birds except M4. The significant nature of this peak in a single bird was emphasized by the duplicate results obtained for Bird M5.

The large differences in oestradiol concentration between birds are reflected in the large standard errors (Text-fig. 1). For example, the maximum concentration of oestradiol in Bird M7 was almost $1 \mathrm{ng} / \mathrm{ml}$ whereas that in Bird M4 was only $160 \mathrm{pg} / \mathrm{ml}$. There was also a difference in the pattern of levels with age between birds, although they all showed the highest levels just before commencing to lay. Four birds (M1, M5, M6 and M7) showed a single distinct peak whereas the other three had subsidiary peaks or a prolonged peak. The mean peak level $(355 \mathrm{pg} / \mathrm{ml})$ was significantly higher than the level 7 weeks before the onset of laying $(94 \mathrm{pg} / \mathrm{ml}, P<0.02)$ and also than the level found subsequently during the laying period $(138 \mathrm{pg} / \mathrm{ml}, P<0.05)$. The mean level 


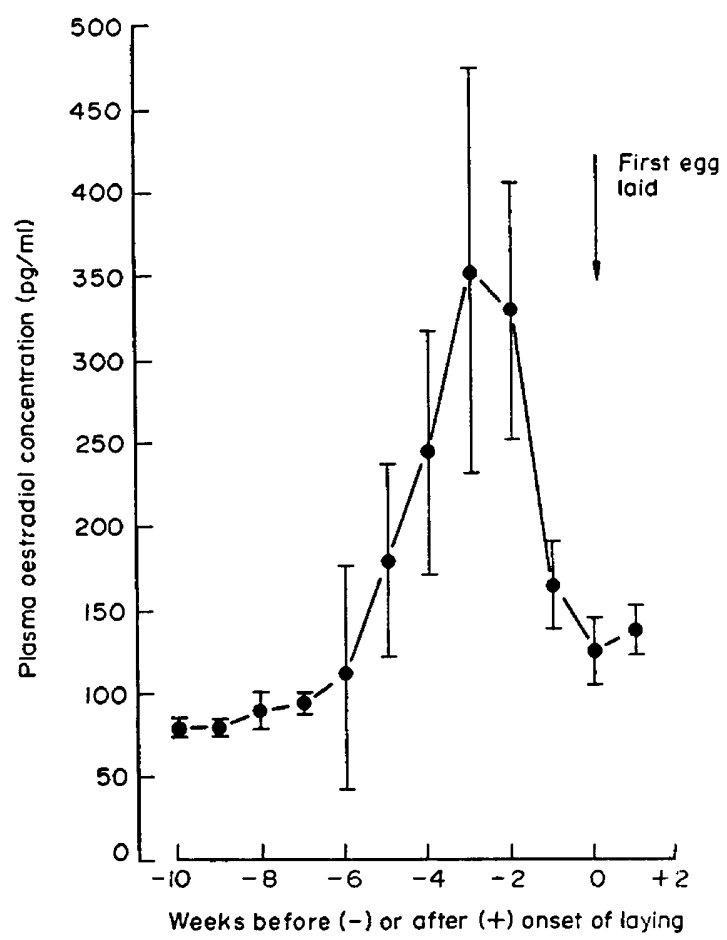

TEXT-FIG. 1. Concentration of oestradiol in the peripheral plasma of pullets approaching sexual maturity. Data from seven birds were pooled with reference to the week during which the first egg was laid. The mean $( \pm$ S.E. $)$ for each time period is shown.

found after egg laying began was significantly higher than that before 10 weeks of age $(P<0 \cdot 001)$.

\section{DISCUSSION}

Pre-laying peaks of several blood constituents have been observed in maturing hens. The concentration in plasma of total proteins (Vanstone et al., 1955), total lipids and fatty acids (Heald \& Badman, 1963) and phospholipoproteins (McIndoe, 1959; Heald \& Badman, 1963) reaches a peak a few days before the onset of laying. These constituents probably, therefore, reach their maximum concentration some time after the oestradiol peak observed in this investigation. Redshaw \& Follett (1972), however, found that the yolk-protein precursor, lipovitellin, whose synthesis by the liver is specifically oestrogen-dependent (Gruber, 1972), reached a peak concentration in plasma 1 to 2 weeks before the onset of laying. The timing of this peak is therefore close to that of oestradiol found in this study. The physiological significance of these observations in relation to the development of the ovarian follicles remains to be elucidated.

Oestrogens (in the presence of androgens) cause an increase in the retention of dietary calcium (Common, Rutledge \& Hale, 1948) and induce medullary bone formation (Benoit \& Clavert, 1945). In maturing birds, medullary bone develops 10 to 14 days before the first egg is laid and the retention of calcium increases from about $100 \mathrm{mg} /$ day to as much as $750 \mathrm{mg}$ /day before laying commences (see Taylor, 1965). The medullary bone is markedly depleted once 
egg production begins (Cox \& Balloun, 1971). The pre-laying peak of oestradiol may, therefore, help in building up the body reserves of calcium in preparation for egg-shell formation.

Common et al. (1965) and Mathur et al. (1966) found that the highest content of oestrone in urine occurred only 'a few days' before laying began. Thus, the time when urinary oestrone levels are high may coincide with the time when plasma oestradiol levels are falling. Such a time relationship, though requiring confirmation in a single experiment, points to the possibility of a marked change in either the metabolism or the excretion rate of oestrogens shortly before the onset of laying. In experiments involving the injection of radioactive oestradiol-17 $\beta$ and oestrone and the determination of urinary metabolites, Common, Mathur, Mulay \& Henneberry (1969) noted that the equilibrium between oestradiol-17 $\beta$ and oestrone was considerably more in favour of oestrone in laying than in non-laying hens. Mathur \& Common (1969) found relatively more oestrone than oestradiol-17 $\beta$ in urine from laying hens than from non-laying hens. This evidence suggests that oestrone becomes relatively more, and oestradiol- $17 \beta$ relatively less important as birds come into lay. Whether such a change is sufficient to account for a simultaneous fall in blood oestradiol levels and rise in urinary oestrone content remains to be determined.

Recent evidence (Cunningham, Bonney, Furr \& Onuora, 1973; P. J. Sharp, personal communication) suggests that the concentration of $\mathrm{LH}$ in the peripheral plasma of pullets rises from 16 weeks of age onwards and may reach a maximum value before the onset of laying. Cunningham et al. (1973) also found that the quantity of $\mathrm{LH}$ released after an injection of synthetic LHreleasing factor (LH-RF) declined to zero between 17 and 21 weeks of age. Just before pullets come into lay, therefore, the rate of synthesis and release of LH may be maximal. The rôle of ovarian steroids in the control of LH release in the hen is still far from clear and the significance of these hormonal changes during the onset of sexual maturity must await further investigation.

The reason for the large variation between birds is not entirely clear although the infrequent sampling intervals may account for some of the differences. The stage at which the ovary begins its cyclic follicular development is uncertain. Wood-Gush \& Gilbert $(1965,1970)$ showed that a considerable number of ovulations occur which are not followed by oviposition, particularly when birds are coming into lay. If the ovary exhibits some form of cyclic activity for some time before the onset of laying, the once-weekly sampling may produce patterns which are confounded by the cyclic phenonenon. Although such an explanation may account for the different patterns found, it is unlikely to be the cause of the differences in mean concentration. Some part of these differences may be due to the variation between assays. As is illustrated by the duplicate values obtained for the same plasma sample in two assays (Bird M5), accuracy was reduced with high levels of oestradiol since the extreme portion of the standard curve was employed. Nevertheless, there may be real differences between birds even within the same strain since Heald \& Badman (1963) also commented on large between-bird differences in their findings.

The reports of Wood-Gush \& Gilbert $(1965,1970)$ that oviposition is not an accurate indicator of ovulation, particularly with birds coming into lay, 
suggests that the time-interval from the peak level of a blood constituent to the time of the first oviposition may be somewhat variable. In further elucidating the process of sexual maturation, it would clearly be preferable to determine metabolic constituents and hormones in the same blood samples.

\section{ACKNOWLEDGMENTS}

This investigation was supported by the British Egg Marketing Board. The author acknowledges the gift from Dr B. V. Caldwell of the antiserum prepared in sheep.

\section{REFERENCES}

Benort, J. \& Clavert, J. (1945) Rôle indispensable des parathyroïdes dans la calcification de l"os folliculinique' chez le canard domestique. C. r. Séanc. Soc. Biol. 139, 743.

Common, R. H., Ainsworth, L., Hertelendy, F. \& Mathur, R. S. (1965) The oestrone content of hen's urine. Can. F. Biochem. 43, 539.

Common, R. H., Mathur, R. S., Mulay, S. \& Henneberry, G. D. (1969) Distribution patterns of in vivo conversion products of injected oestradiol $-17 \beta-4-{ }^{14} \mathrm{C}$ and oestrone-4- ${ }^{14} \mathrm{C}$ in the urines of non-laying and laying hens. Can. F. Biochem. 47, 539 .

Common, R. H., Rutledge, N. A. \& Hale, R. W. (1948) Observations on the mineral metabolism of pullets. 8. The influence of gonadal hormones on the retention of calcium and phosphorus. $\mathcal{F}$. agric. Sci., Camb. 38, 64.

Cox, A. G. \& Balloun, S. L. (1971) Depletion of femur bone mineral after the onset of egg production in a commercial strain of leghorns and in broiler-type pullets. Poult. Sci. 50, 1429.

Gunningham, F. J., Bonney, R. G., Furr, B. J. A. \& Onuora, G. I. (1973) The effect of synthetic luteinizing hormone releasing factor on plasma levels of luteinizing hormone in the domestic fowl. F. Endocr. 59, xiv.

Gilbert, A. B. (1971) Control of ovulation. In Physiology and Biochemistry of the Domestic Fowl, vol. 3, p. 1225. Eds. D. J. Bell and B. M. Freeman. Academic Press, London.

Gruber, M. (1972) Hormonal control of yolk protein synthesis. In Egg Formation and Production, p. 23. Eds. B. M. Freeman and P. E. Lake. British Poultry Science Ltd, Edinburgh.

Heald, P. J. \& Badman, H. G. (1963) Lipid metabolism and the laying hen. 1. Plasma free fatty acids and the onset of laying in the domestic fowl. Biochim. biophys. Acta, 70, 381.

Kyes, P. \& Potter, T. S. (1934) Physiological marrow ossification in female pigeons. Anat. Rec. 60, 377.

Lorenz, F. W. (1954) Effects of oestrogens on domestic fowl and applications in the poultry industry. Vitams Horm. 12, 235.

McIndoz, W. M. (1959) A lipophosphoprotein complex in hen plasma associated with yolk production. Biochem. 7. 72, 153.

MathuR, R. S., Anastassiadis, P. A. \& Common, R. H. (1966) Urinary excretion of estrone and of 16-epiestriol plus 17-epiestriol by the hen. Poult. Sci. 45, 946.

Mathur, R. S. \& Common, R. H. (1969) A note on the daily urinary excretion of estradiol-17 $\beta$ and estrone by the hen. Poult. Sci. 48, 100.

Redshaw, M. R. \& Follett, B. K. (1972) The physiology of egg yolk production in the hen. In Egg Formation and Production, p. 35. Eds. B. M. Freeman and P. E. Lake. British Poultry Ścience Ltd, Edinburgh.

SEnIOR, B. E. (1973) Oestrogens in the domestic fowl. Ph.D. thesis, University of Reading.

SENIOR, B. E. (1974) Radioimmunoassay of oestrone and oestradiol in the peripheral plasma of the domestic fowl in various physiological states and of hypophysectomized and ovariectomized fowls. Acta endocr., Copenh. 75, 133.

Simkiss, K. (1967) Calcium metabolism in the laying bird. In Calcium in Reproductive Physiology, p. 155. By K. Simkiss. Ghapman \& Hall, London.

TAYLOR, T. G. (1965) Calcium-endocrine relationships in the laying hen. Proc. Nutr. Soc. 24, 49.

URIST, M. R. (1959) The effects of calcium deprivation upon the blood, adrenal cortex, ovary and skeleton in domestic fowl. Recent Prog. Horm. Res. 15, 455.

Vanstone, W. E., Maw, W. A. \& Common, R. H. (1955) Levels and partition of the fowl's serum proteins in relation to age and egg production. Can. F. Biochem. 33, 891.

Wood-Gush, D. G. M. \& Gilbert, A. B. (1965) Relationship between the ovary and the oviduct in the domestic hen. Nature, Lond. 207, 1210.

Wood-Gush, D. G. M. \& Gilbert, A. B. (1970) The rate of egg loss through internal laying. Br. Poult. Sci. 11, 161 . 